
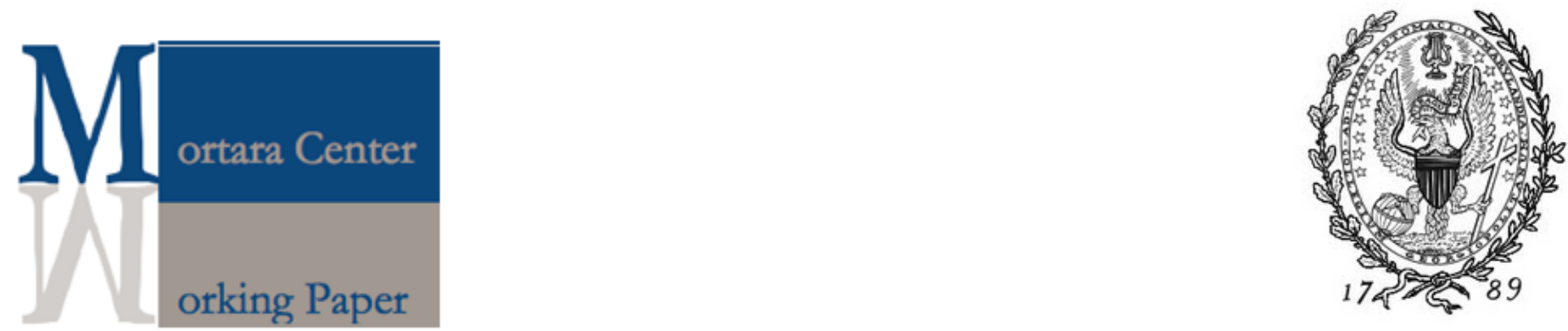

\title{
Has the Pakistan Army Islamized? What the Data Suggest
}

\section{Christine Fair}

Georgetown University

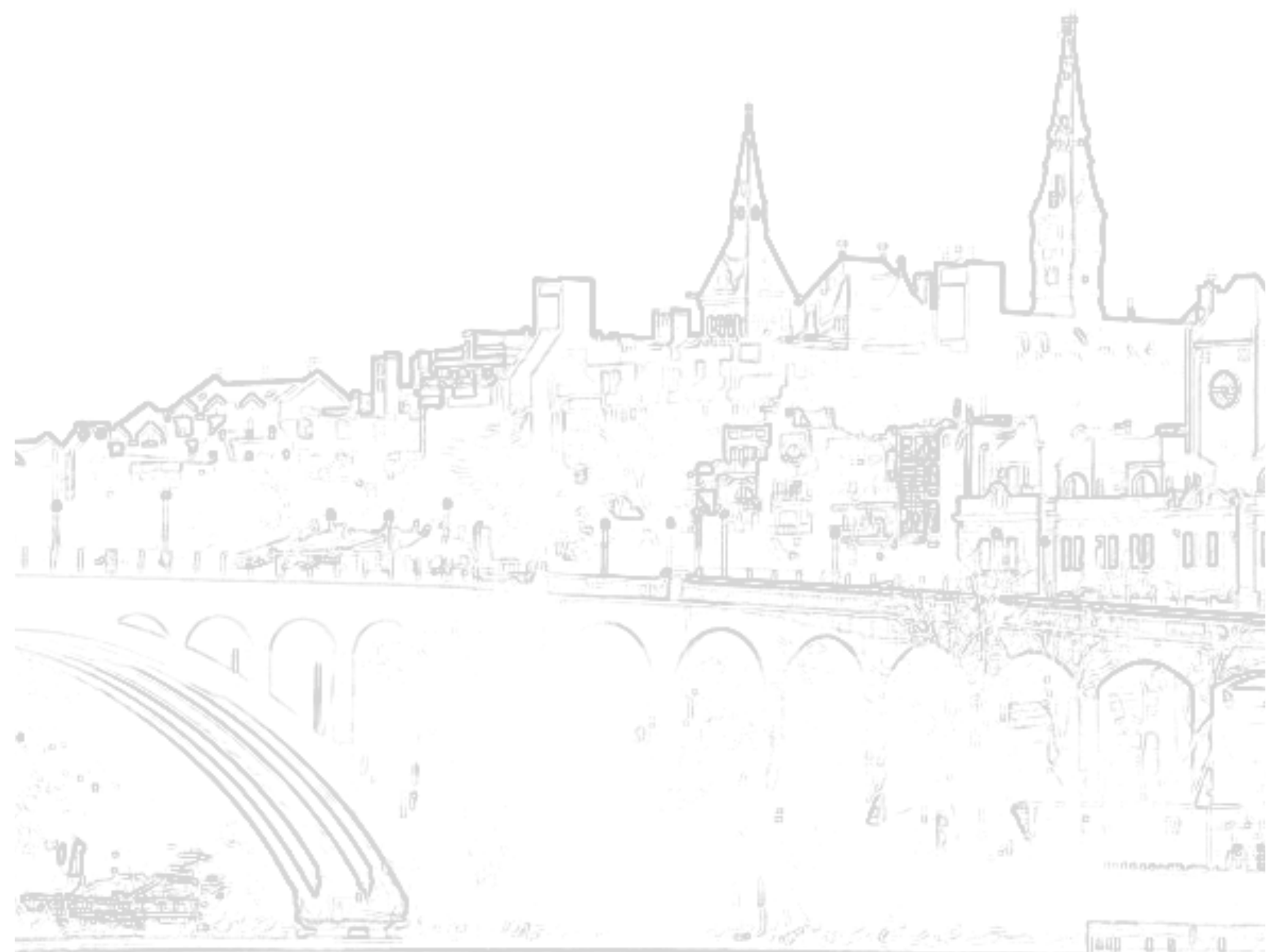

Mortara Working Paper 2011-13

Mortara Center for International Studies

September 2011 Edmund A. Walsh School of Foreign Service Georgetown University 


\author{
C. Christine Fair
}

September 7, 2011

\title{
ACKNOWLEDGEMENTS:
}

The author thanks Stephen P. Cohen, Ron Hassner, Jacob N. Shapiro, Graeme Blair, Claude Berrebi and two anonymous reviewers for their helpful critiques of this work at various stages in analysis in writing. The author also is grateful to Anirban Ghosh for assistance in data management. The author alone is responsible for any errors of fact or interpretation.

\section{ABOUT THE AUTHOR:}

C. Christine Fair is an assistant professor in the Center for Peace and Security Studies (CPASS) within Georgetown University's Edmund A. Walsh School of Foreign Service.

\section{ABSTRACT:}

This essay interrogates popular beliefs about Islamization of the Pakistan Army officer corps and the polity from which the army recruits. It first assembles and synthesizes the extant secondary literature on Islamization of Pakistan generally, and the army in particular. As access to the Pakistan Army diminished after 1990 when numerous U.S. sanctions on Pakistan limited defense cooperation and other forms of bilateral engagements were imposed, this secondary literature is generally truncated to 1990. To expand what is known about the Pakistan Army, this essay next presents the results of an ongoing quantitative analysis of district-level officer recruitment (and retirement data). This ecological study finds that districts that produce army officers are actually more socially liberal and urban than is commonly believed. This essay discusses the implications of the changes in the officer corps and concludes with a call for a robust research agenda on the Pakistan Army.

Key words: Pakistan army, Islamization, Islamist militancy, US-Pakistan relations. 


\section{INTRODUCTION TO THE PAKISTAN POLICY DILEMMA}

Policymakers and analysts have long worried about the purported Islamization of the Pakistan Army, fearing that some military personnel may support Islamist terrorism in the region and beyond. ${ }^{1}$ Others frequently equate this supposed greater Islamization with deepening antiAmericanism within the army. ${ }^{2}$ Three inter-related concerns undergird these apprehensions about the Pakistan army. First, the Pakistan Army has relied upon Islamists and Islamist militants alike to prosecute its interests in India and Afghanistan since 1947 and 1960 respectively and analysts and policymakers alike worry that some army personnel may sympathize deeply with the worldview of their past and current clients. ${ }^{3}$

Second, some observers fear that a "radical, rogue Islamist" column may split off within the army. ${ }^{4}$ Sometimes this is manifested in alarming speculation that the Pakistan Army has "Islamized," often without consideration to what "Islamization" means. ${ }^{5}$ In extrema, these posited rogue elements could break away from the army and undermine the state. They could surreptitiously support Islamist militancy beyond the purview of the army and Pakistani intelligence agencies such as the Inter-Services Intelligence Directorate (ISI), Military Intelligence, and the Intelligence Bureau. ${ }^{6}$

Third, analysts and observers of the Pakistan army worry that military or other government personnel may provide terrorists with nuclear materials, know-how, or perhaps even fully constructed nuclear weapons. ${ }^{7}$ Concerns about terrorist acquisition of nuclear materials have intensified since late May 2011 when terrorists associated with the Pakistani Taliban launched a complex attack on a major naval base in Karachi. Pakistani journalists reported that the operation was facilitated by an al Qaeda cell within the Pakistan Navy. ${ }^{8}$ This was only one of numerous attacks on military targets that involved inside assistance from uniformed and civilian 
personnel within the armed forces, including: two attempts to assassinate former President Pervez Musharraf; ${ }^{9}$ the 2007 suicide raid on army commandos at a high security facility in Tarbela ${ }^{10}$ the 2009 attack on Army General Headquarters by militants in military uniforms; ${ }^{11}$ among other assaults on military, intelligence, police, and other federal and provincial facilities. ${ }^{12}$ With the frequency of such attacks involving terrorist infiltration of the forces, Pakistanis too are increasingly concerned about the integrity of their national security institutions and the degree to which they have been compromised by the enemy within. ${ }^{13}$

Thus Pakistan conjures the most horrific and intertwined specters of nuclear proliferation and international terrorism in U.S. policy discourses - and increasingly so within the Pakistani public debates as well. ${ }^{14}$ In recent months, materials pilfered from U.S. officials by WikiLeaks have brought even classified discussions of these fears into the public domain. ${ }^{15}$ Equally disconcerting is the widespread tendency within U.S. policy circles to assume that deepening commitments to political Islam (Islamism) or increasing personal piety or even conservatism is coincident with a greater propensity to support Islamist militancy in Pakistan relative to those who are presumed to be "liberal" or even "secular."

These frequently and publicly discussed concerns about the Islamization or even radicalization of the Pakistan Army exist despite the gaping absence of solid evidence for the most capacious versions of the claim. However, continued instances of militant infiltration of the armed forces make it impossible to dismiss this concern out of hand. This public speculation in the absence of evidence is counterproductive to building a better rapport between the United States and Pakistan at governmental and popular levels in part because many Pakistanis of various political and ideological orientations bristle at assertions that appear to them to be patently anti-Muslim. ${ }^{17}$ In particular, repeated U.S. demands that Pakistan "do more" to weed 
out the threats from within may breed further mistrust between the countries' armed forces. Increasing estrangement between the armed forces in turn fosters ever more distrust.

Despite the importance of understanding the depth of Islamization, much less radicalization of the Pakistan Army, scholarship on this subject is virtually non-existent. Scholarship generally on the Pakistan Army is surprisingly thin or dated, given the importance of the institution to regional and international security. Stephen P. Cohen's The Pakistan Army remains the most empirical analysis of the organization. However, that volume was published in 1984, and many events have transpired since his research. ${ }^{18}$ Ayesha Jalal's The State of Martial Rule: The Origins of Pakistan's Political Economy of Defence (1990) remains one of the best and most authoritative accounts of the rise of authoritarianism in Pakistan. However, her volume was published in 1990, some two decades ago. ${ }^{19}$ Hassan Askari Rizvi's volumes Military, State and Society in Pakistan (2000) and The Military and Politics in Pakistan: 1947-1997(2000) remain the most insightful works on Pakistan's civil-military relations. ${ }^{20}$ Other recent work by Ayesha Siddiqa and Shuja Nawaz address the rise of the army in managing the state and Pakistan's fraught civil-military relations. ${ }^{21}$ However these esteemed scholars of the Pakistan Army do not dilate upon the issue of Islamization within the Pakistani military, much less radicalization and active collaboration with terrorists, with the exception of Cohen. However, Cohen's fieldwork was completed circa 1980, before the impacts of President and General Zia al Haq's Islamization efforts and the effects of the anti-Soviet Afghan jihad could be observed.

Husain Haqqani’s Pakistan: Between Mosque and Military(2005) is an important account the army's adoption of a primary objective of protecting the "ideology of Pakistan." It is not an examination of the role of Islam within the army's strategic culture; rather, his volume speaks to the way in which the military and other organs of the state have instrumentalized Islam 
for state building, nation building, achieving external goals in India and Afghanistan, and minimizing internal identity fissures within Pakistan. ${ }^{22}$ Rizvan Hussain's volume, Pakistan and the Rise of Islamic Militancy in Afghanistan, covers similar ground to that of Haqqani, with a more intense focus upon the role of the army in supporting Islamist militias to manage events in Afghanistan. ${ }^{23}$ While these volumes both address how the military used Islam, neither discusses how the armed forces have been affected by these policies (if at all).

One of the reasons for this paucity of recent scholarship about the Pakistan Army is that access to that institution has constricted since 1990, when the United States cut off all military assistance to Pakistan due to nuclear proliferation. As Pakistan was dependent upon U.S. weapons systems, this cutoff significantly degraded Pakistan's conventional capabilities as it was unable to secure spare parts or benefit from U.S. maintenance programs for F-16s, among other U.S. platforms. These sanctions also made it extremely difficult for Americans to garner insights into the Pakistan Army, because they excluded Pakistan from the U.S. International Military Education Training (IMET) program and cut off almost all ties between the countries' defense establishments. Consequently, throughout the 1990s, contacts between U.S. and Pakistani military personnel were limited to United Nations peacekeeping missions. ${ }^{24}$ Apart from the United States, Pakistan's other key military partners are Saudi Arabia and China, and there is no transparency in these relationships.

Since 1990, Pakistanis came to view Americans as adversaries keen on shutting down Pakistan's nuclear weapons program. These concerns have intensified rather than tempered since the United States and Pakistan resumed (some degree) of cooperation after 9/11. ${ }^{25}$ The May 2011 unilateral attack by U.S. Navy SEAL teams to kill and extract Osama Bin Laden from 
a Pakistan army cantonment town exacerbated these fears and stoked concerns that the United States - or even India - could conduct similar attacks on Pakistan's nuclear facilities. ${ }^{26}$

Pakistan's intelligence agencies and the army itself closely monitor which officers can interact with foreign military counterparts, rigorously screen those who go abroad, and circumscribe socializing with foreign military personnel attending training institutions within Pakistan. ${ }^{27}$ The Pakistan Army and intelligence agencies also carefully orchestrate foreigners' contact with the army in the country. U.S. officials — both civilian and military — rarely meet officers below the rank of Lt. Colonel, with the exception of those U.S. Army Majors who attend the Command and Staff College for one year at Quetta. U.S. defense analysts have told this author that U.S. officials interact with about 100 Pakistani officers at most. They meet no junior non-commissioned officers and no enlisted soldiers despite an active army that is comprised of some 550,000 personnel, including tens of thousands in the officer corps. ${ }^{28}$

Gaining access to the army's personnel and educational and training institutions is extremely daunting and a significant deterrent to anyone seeking to undertake such a study in the first place. Given that Pakistan, unlike the United States, does not have a public national security strategy or a culture of defending national security concerns in the parliament, there are few published or other public means to garner insights into the Pakistan Army. For these, among other reasons, the scholarly secondary literature on the Pakistan army is truncated to the early 1990s when access narrowed.

In the absence of information and visibility into the institution, concerns about the Pakistan army and the posited "Islamists within" have only intensified over the last ten years. U.S. analysts talk about "beard counts" at the graduation ceremonies at the National Defense University and they keep track of officers who are presumed to have "Islamist" credentials, 
fearing that they may be the mastermind of the next insidious terror attack against India, or a purveyor of nuclear technology to terrorists, among other nightmare scenarios. ${ }^{29}$

This essay seeks in some measure to synthesize qualitative and new quantitative data to cast light on the role of Islam in the officer corps of the Pakistan Army. The remainder of this essay is organized as follows. In the next section, I provide a brief introduction to recruitment in the Pakistan Army. In the third section, I briefly review the literature on the Islamization of Pakistan followed by a review of the available, albeit scant, literature on Islamization of the Pakistan Army specifically in the fourth section. Fifth, I present evidence from a unique database of the districts which produce most Pakistani army officers. This is an ecological analysis of district-level recruitment data: it is not an analysis of officers themselves. This paper concludes with a call for a solid research agenda on religion in the Pakistani military. Such an agenda should include new data collection to inform these issues, given the numerous and pressing policy concerns that stem from them.

\section{RECRUITMENT IN THE PAKISTAN ARM Y ${ }^{30}$}

Pakistan's army is an all volunteer army. The principal institution that trains Pakistani army officers is the Pakistan Military Academy (PMA) at Kakul. Each year, the PMA conducts two long courses, with one cohort inducted in the spring and another in the fall. After graduating from the two-year programs, cadets are commissioned with the rank of second lieutenant. ${ }^{31}$ The selection process is extremely competitive with far more applicants than billets. Candidates must satisfy a number of eligibility criteria: they must be single, hold at least an intermediate degree (i.e., 12 years of schooling), and be between 17 and 22 years of age. Recruits must obtain a score of at least 50 percent in their matriculation (10th grade) or FA (12th grade) exams. ${ }^{32}$ 
Applicants undergo initial testing and screening at eight regional selection and recruitment centers across the country: Rawalpindi, Lahore, and Multan (in the province of the Punjab); Hyderabad and Karachi (in the province of Sindh); Quetta (in the province of Baluchistan), Peshawar (in the province of Khyber-Pakhtunkhwa (KPK, formerly NWFP); and Gilgit (in the administrative area of Gilgit-Baltistan, previously known as the "Northern Areas"). ${ }^{33}$ Selected candidates next proceed to Inter-Services/General Headquarters Selection and Review Board in Kohat or satellite centers in Gujranwala (Punjab), Malir (Sindh), or Quetta (Balochistan) for further arduous screening process. Successful candidates are then recommended for the PMA. Each year, the Army General Headquarters determines the precise number of slots for PMA cadets based upon regimental reports on shortfalls. As the previous discussion indicates, officer selection is generally based upon on merit with the exception of episodic efforts to enhance prospects from provinces such as Sindh and Balochistan which are considerably underrepresented in the officer corps. ${ }^{34}$

\section{BACKGROUND: ISLAMIZATION OF PAKISTAN?}

The Pakistan Army previously drew from elite families from the Punjab as well as what is now called KPK, reflecting the British colonial recruitment patterns and reliance upon the British notion of "martial races." ${ }^{35}$ Since 1947, the Pakistan Army has increasingly moved away from this and has come to resemble ever more the society from it which draws. For this reason, a discussion of the Islamization of Pakistan is important. ${ }^{36}$ That said, the Pakistan Army, which has governed the state directly for more than half of its history and governed indirectly for the balance, has been an active agent in Islamizing Pakistan. 
The current role of Islam as increasingly defining Pakistani statehood and citizenship, in large measure, derives from the "two-nation" theory which was the motivating logic for the Pakistan independence movement. According to this thesis, Muslims comprised a separate nation from either Sikhs or Hindus of the British Raj. To ensure the protection and rights of Muslims, they required their own state. Muslim proponents of the two-nation theory feared that if Muslims were to remain within a united India, their interests would not be protected in a Hindu majority state. While Pakistan was imagined to be the homeland $\mathrm{f} \square$ 
among other efforts to promote his notion of Islamic socialism; and enshrined Islamization within the new 1973 constitution, which for the first time clearly stated that Pakistan was an Islamic state. ${ }^{39}$

After 1977, President General Zia ul Haq worked to strengthen the place of Sunni Islam within the Pakistani state and polity. ${ }^{40}$ Zia's Islamization efforts were "regulative, punitive, and extractive." 41 Among other numerous initiatives, Zia's regime promulgated "The Hudood Ordinances" in 1979 to enforce Islamic punishments for various crimes. ${ }^{42}$ Zia also introduced interest-free banking based upon an alternative system of profit and loss sharing and a highly controversial system of compulsory Islamic tax, zakat. ${ }^{43}$ A sharia faculty was established in the Qaid-e-Azam University in Islamabad in late 1979 and later a separate Islamic University was established in Islamabad with the financial assistance of the Arab states of the Persian Gulf. In addition, the courses and syllabuses of schools and colleges were revised to provide a greater emphasis upon the "Ideology of Pakistan" as well as Islamic principles and teachings. The electronic media and press were informed that their content should reflect orthodox Islamic values. In addition, obligatory prayer breaks were imposed during working hours within government offices and private sector employers were encouraged to the do the same. ${ }^{44}$

As Zia's tenure evolved, he invoked Islamization to justify his martial law regime. He relied upon Islamization ever more intensely after he failed to hold promised elections and as the goals of his regime expanded amidst declining legitimacy. ${ }^{45}$ Nonetheless, Islamization of society was hindered by the diversity of Islamic schools of thought in Pakistan, most of which contest the fundamental lineaments of sharia. Thus, imposing sharia became a struggle over which sharia would be imposed. Another impediment was and remains the lack of clerical hierarchy in Pakistan’s Sunni traditions. 
Contrary to the view that Islamic revivalism would be more popular among illiterate rural Pakistanis, it has been decidedly an urban phenomenon. Cities have been the loci for Islamist discourse and it is in cities where Islamist policies and actions have been formulated by its proponents, including Islamist political parties and their student wings, as well as ulema. (Most of Pakistan's most influential madaris [plural of madrassah] are in Pakistan's major cities and these madaris host the country's most prominent $u l e m a{ }^{46}$ ) As Qadeer, among others, has noted, "Urban Islam tends to be relatively puritanical and textual compared to the ritual/folk thrust of beliefs and practices in rural/tribal areas." ${ }^{, 47}$

Similarly, scholars of Islam in Pakistan contend that Islamic revivalism tends to be rooted among the newly educated and prospering groups which tend to be cosmopolitan in outlook and lifestyle despite their personal piety. ${ }^{48}$ This observation is extremely important, as most Western scholars assume that cosmopolitan lifestyles suggest greater propensity towards religious liberalism or even secularism. In Pakistan, this need not be the case: ostensibly Westernized urban elites may be deeply pious despite the conspicuous aspects of their lifestyles. Another curious feature of Islam in Pakistan is that personal piety does not translate into voting preferences for Islamist parties. Islamist parties have never fared well at the polls, usually taking less than ten percent of the total ballots cast. ${ }^{49}$ Voting behavior is dictated more by family, clan and patronage networks than by personal piety or lack thereof. ${ }^{50}$

There is no way to empirically demonstrate the impacts of these various trends upon Pakistanis' views towards Islamism, militancy, or piety, much less the views on these subjects held by personnel in the Pakistan Army. Simply put, while the historical accounts posit a slow but steady process of Islamization of Pakistani institutions - including the army and civil society — this research finds few consistent measures of this in Pakistani public opinion polls. ${ }^{51}$ 
Moreover, most surveys of Pakistan have been conducted after September 11, 2001 and thus do not permit and assessment of trends prior to this date. ${ }^{52}$ None of these surveys permit identification of military households, much less specific officers, and none have the sample size that permit analysis of views of military households or officers, even if they included variables that indicated that either the respondent was an officer or whether the household included such persons. ${ }^{53}$

\section{ISLAMIZATION AND THE PAKISTAN ARMY}

The role of Islam within the Pakistan Army remains a contested and highly volatile area of inquiry with vocal opponents and proponents of the notion that the Pakistan Army has "Islamized." Unfortunately, as noted above, the scholarly literature on this subject is very slender and extremely dated. A perusal of the secondary literature on this subject suggests there are at least four aims of the military's mobilization of Islam.

First, as Cohen observed in 1984, the Pakistan Army "moved immediately to emphasize Islam as a unifying force. ${ }^{, 54}$ When Pakistan came into being, the state had two wings: East and West Pakistan. East Pakistan was nearly exclusively ethnic Bengalis who had virtually no representation in the new government or armed forces. Bengali ethno-nationalist aspirations emerged early in Pakistan's history. Their increasing disgruntlement was a challenge to the unity of the nascent state because they were the majority of Pakistan's population.

In contrast, West Pakistan had four main provinces: Punjab dominated by ethnic Punjabis; Sindh dominated by ethnic Sindhis; Balochistan with a mostly Baloch population, and the Northwest Frontier Province (now KPK) which was populated by a majority of Pashtuns who are also a majority in Pakistan's Federally Administered Tribal Areas (FATA) and who have 
consanguineal ties to ethnic Pashtuns in Afghanistan. Additionally, there are several smaller ethnic groups in Gilgit-Baltistan, as well as Kashmiris living in Pakistan-administered Kashmir.

Pakistanis in West Pakistan were heterogeneous in their support for an independent Pakistani state, the kind of state it should be, and their interests in becoming citizens of the state. In Balochistan, as elsewhere in the British Raj, the British had a relationship of paramountacy with Indian states or principalities which granted them considerable internal autonomy at the cost of owing fealty to the British. In what is now Balochistan, there was such an independent territory called the Khanate of Kalat. However, unlike other principalities, the Khanate of Kalat did not have a treaty with the British Indian government rather with Whitehall. Thus, the legality of its succession to Pakistan was contested by Baloch proponents of an independent Baloch state. The Khan (leader) of Kalat (Mir Ahmad Yar Khan) declared independence one day after Pakistan became independent. Ultimately, Pakistan annexed it by force. Some Baloch tribes have waged an insurgency since independence, rejecting their inclusion in the state from first principles. $^{55}$

Many Pashtuns in what is now KPK resisted inclusion to the new state with some Pashtuns objecting to partition, others even wanting to join India, while others yet preferring a greater Pashtunistan (also known as Pakhtunkhwa) which would include Afghan territories dominated by Pashtun co-ethnics. Some proponents of Pashtunistan, drawing upon historical arguments, sought to include Balochistan in their Pashtunistan.

A shared irritant in West and East Pakistan alike was the imposition of Urdu as the national language, which was the mother tongue only of the "Muhajirs" (Urdu speaking people who migrated to Pakistan from North India during or immediately after partition). There was no area of Pakistan where Urdu was the mother tongue, which discomfited non-Urdu speakers. As 
the Muhajirs settled in Karachi, the major city of Sindh, ethnic clashes began early on between Sindhis and Muhajirs. Later, as Karachi became a multi-ethnic city due to migration, other clashes emerged among Sindhis, Muhajirs, Baloch and Pashtuns. Karachi remains a powder keg of (often violent) ethnic and sectarian rivalries. ${ }^{56}$

Military and civilian leaders alike used Islam to help the state cohere by imposing an identity that could supersede ethnic affiliations. During both the 1965 and 1971 wars, Islam was repeatedly invoked to mobilize the civilians as well as soldiers. ${ }^{57}$ However, not all versions of "Islam" are equal. The military patronized different sectarian traditions of Sunni Islam, to the discomfort of Shia, Ahmediyyas, Sufis and non-Muslim minorities. ${ }^{58}$

During General Yayha Khan's tenure (Pakistan's second military ruler), the army began assuming a new role, defending Pakistan's "ideological frontiers," in addition to the state's territorial sovereignty. ${ }^{59}$ Zia ul Haq expanded this commitment and explained that "Pakistan's armed forces were responsible for not only safeguarding the country's territorial integrity but also its ideological basis. ${ }^{, 60} \mathrm{Zia}$ further elaborated that the "preservation of that ideology and the Islamic character of the country was... as important as the security of the country's geographic boundaries." ${ }^{\prime 61}$

A second goal advanced by the army's use of Islam is motivating soldiers to fight an enemy that has always been conventionally superior: India. Cheema, in his discussion of army officer training at the Pakistan Military Academy and other training institutions such as the National University of Science and Technology, notes that underlying these educational programs "is a strong grounding in general Islamic teaching including the concept of Jihad. This is inevitable in a Muslim country: the concept of Jihad is an important pillar of Islam." ${ }^{62}$ In fact, 
to ensure that soldiers have a solid understanding of the "concept of Jihad," teaching this concept has become an integral part of training in the armed forces." ${ }^{63}$

Cheema believes the army sees this as necessary because Pakistan confronts a larger, better equipped Indian Army. The Pakistan Army must therefore rely heavily upon a "great measure of moral superiority which encompasses a high degree of professional competence, indepth study of modern concepts and doctrines of war, better leadership and inspired ideological orientations. ${ }^{.64}$

Islam also bolsters the army's will to fight by debasing and demeaning the enemy. During the civil war of 1971, the Commander-in-Chief and President of Pakistan, Yahya Khan, motivated his soldiers by declaring the Mukti Bahini (the Bengali guerillas) to be a "kafir" army against which the Pakistan army was waging a legitimate jihad. ${ }^{65}$ Brigadier Javed Hassan (who retired a Major General), while at the Faculty of Research and Doctrinal Studies (FORAD) at the Command and Staff College in Quetta, conducted and published a study titled India: A Study in Profile ${ }^{66}$ It is now required reading at the National Defense University as well. ${ }^{67}$ In this volume, the author derides India by arguing that India is not a nation, characterizing India's past as having a "total absence of any popular resistance against foreign domination and rule," denounces the Indians as "less warlike," ${ }^{, 9}$ attributes India's military failures to "racial" shortcomings, ${ }^{70}$ among other derogatory characteristics of Hindus and Hinduism. ${ }^{71}$ Of course, it needs to be stated that India has never lost a war with Pakistan.

Fourth, the Pakistan Army and the intelligence agency it controls (the ISI) have relied upon Islam to prosecute its interests in Afghanistan since 1960 when it interjected Jamaat-eIslami (JI) into the country. Many mujahidin commanders who fought in the anti-Soviet jihad (e.g. Gulbuddin Hekmatyar, Ahmad Shah Masood, and Maulvi Mohammad Yunus Khalis, 
among others) had JI backgrounds. After the Soviet withdrawal and as Afghanistan succumbed to internecine warfare, Pakistan supported Gulbadin Hekmatyar (an Islamist Pashtun) in the hope that he could pacify Afghanistan and ensure it remained tilted towards Pakistan. When he demonstrated repeatedly to Army General Headquarters and the ISI that he could not do so, Pakistan began patronizing the Deobandi Taliban. ${ }^{72}$ Pakistan has also relied upon a bevy of Sunni Islamist militant groups to achieve Pakistan's interests in Indian-administered Kashmir and elsewhere in India. Many of these groups had their origins in the anti-Soviet jihad and were subsequently redeployed to India. These groups come from Ahl-e-Hadith, JI, Deobandi backgrounds. After 1990, these Islamist militant groups, operating at Pakistan's behest, aimed to undermine groups like the Jammu Kashmir Liberation Front, which fought India on the basis of their ethnic Kashmiri identity. ${ }^{73}$

\section{Means of Achieving Goals of I slamism of the Army}

The Pakistan Army has sought to achieve these means over time through a variety of active efforts as well as developments that transpired in recent decades. Reflecting Zia's personal piety and Islamization agenda, immediately after becoming army chief in March 1976, he promulgated a new army motto: Iman (Faith), Taqwa (Piety and Abstinence), and Jihad-fisibilillah (holy war in the name of god). ${ }^{74}$

Zia was very sympathetic to JI in particular and used his post of army chief to allow the distribution of the party's literature among the officers and rank and file. This allowed JI to make inroads into the army and other services as many officers also began overtly affiliating with JI and its founder Maulana Maududi. ${ }^{75}$ Zia permitted other Islamic groups, such as the Tablighi Jamaat, to expand their presence in the army too. (Tablighi Jamaat is a revivalist group dedicated to proselytization and claims to eschew political activities.) Zia was the first head of state to 
attend its annual meeting in Raiwind (in the Punjab, near Lahore), which encouraged several officers to openly associate with the group to demonstrate their piety. ${ }^{76}$ This would have been anathema to past army chiefs.

Hasan Askari Rizvi, however, has written that while the adoption of this motto reflected Zia's personal religious inclinations, it was not a major departure from the Pakistan Army's culture because its military education always emphasized Islamic principles, teachings, history and Muslim war heroes and their battles. ${ }^{77}$

Under Zia, Islamic training was introduced in the curriculum of the Command and Staff College. Cohen drew attention to the lectures of Col. Abdul Qayyum at the Staff College throughout the 1970s. (These were ultimately printed in book format with a foreword by Zia.) Qayyum encouraged officers to respect mullahs and maulvis and understood these "clerical" figures - despite their various degrees of religious scholarly achievement or lack thereof - to be a bridge for the officer that could span his "Westernized profession and his faith." ${ }^{78}$ Qayyum urged students to take the Quran as the base of their education.

Cohen also found that the army's professional journals contained numerous essays that studied the question of Islamization of the military and the degree to which the Pakistan Army should part ways with the traditional practices of the old Indian army to achieve greater adherence to Islamic principles. For example, the regiments took on distinct Islamic battle cries. The Pakistan Frontier Force adopted "Nadar Hazar Ali!" ("I am present before the Almighty!"). Signboards reminded recruits that, "Life and death are the same thing: and when the experiment of life is completed, then the eternal life — which we call death — begins." Other boards declared that, "Fighting in the name of Allah, fighting in the name of truth, is the supreme sort of 
worship; and anybody who does service in the armed forces with the intention of doing this job in worship, his life is worship."79

Rizvi has identified several other developments that took place within Zia's army that had far-reaching impacts upon the role of Islam in the army. First, Zia'a encouragement of Islamic orthodoxy within the army coincided with subtle changes in recruitment patterns in the army, which increasingly saw officers coming from middle to lower socioeconomic strata as well as increasingly from urban areas and small towns where conservative Islamic ideology is more prevalent than in rural Pakistan. Thus the values that Zia promulgated in the army were in alignment with those of the new Pakistani soldier. ${ }^{80}$

Second, Zia also upgraded the maulvis's status and required them to go to battle with the troops. Prior to Zia's tenure, maulvis were considered to be somewhat comical figures both within and outside the army. ${ }^{81} \mathrm{~A}$ maulvi is technically one who has completed a formal course of religious education at a madrassah. Typically, this takes about eight or more years to complete. In reality, few "maulvis" or "mullahs" have completed this rigorous course of study; rather many have at most completed only a few years of formal religious studies and many are barely literate in any language. Traditionally, maulvis or mullahs have not received a salary for their mosquerelated duties; rather, they live off of the generosity of the local community they serve. The maulvis' lack of genuine religious knowledge and social status encourages many Pakistanis pious or otherwise - to see them as charlatans more worthy of derision than reverence. The persistent rumors of their pederast tendencies provide further fodder for the rich culture of jokes about them.

Third, under Zia, the degree to which officers embraced Islamic conservatism influenced their promotion paths in part because he viewed it as "an important part of the public profile of 
the in-service personnel." ${ }^{, 82}$ While officers' private lives were always under scrutiny, under Zia an officer's piety and religious practice became a part of his assessment for promotion. This may have encouraged some officers to begin growing beards and eschewing alcohol — which had long been the purview of officers relaxing at their various officers' messes. ${ }^{83}$

Fifth, officers (and soldiers) also did military assignments with militaries of Arab states of the Persian Gulf which also exposed them to orthodox (often Wahhabist) teachings. ${ }^{84}$ Unfortunately, very little has been written about this cooperation. Writing in 1986, Jamal Rashid notes that between 40,000 to 50,000 Pakistani military personnel were serving abroad, with the largest commitment to Saudi Arabia. In the 1980s, Pakistan exported an entire independent armored brigade to Saudi Arabia. ${ }^{85}$ As of 1986, Pakistan had one division (approximately 13,000 men), two armored and two artillery brigades (approximately 10,000 men), and several naval and air force personnel stationed in Saudi Arabia. ${ }^{86}$ In addition to these associations with Saudi Arabia, Pakistani air force pilots could enhance their chances of promotion, at least at one point, by flying with the United Emirates Air Force. Pakistan continues to provide technical and training assistance to the United Arab Emirates, Saudi Arabia, Kuwait, Bahrain and Qatar. ${ }^{87}$

Pakistan does not publicize its foreign deployments apart from United Nations Peace Keeping missions. Thus, it is impossible to verify with public sources their current deployments in the Middle East. Recent reporting suggests that Pakistan has a battalion of the Azad Kashmir Regiment in Bahrain, which was deployed in 2010 to train local troops. Pakistan also sends retired officers to augment Bahrain's military capabilities. Prime Minister Yousuf Gillani, in March of 2011, assured Bahrain's foreign minister that Pakistan would dispatch more retired manpower to quell the unrest by Bahrain's Shia majority against the Sunni rulers. This same 
report estimates that there are about 10,000 serving and retired Pakistani military personnel currently in Bahrain. ${ }^{88}$

The long association with the Pakistani armed forces in Arab states of the Persian Gulf raises an important - if unanswerable — question: did this exposure to these states and Wahhabism encourage Islamism among those who served in these states and those who interacted with them, including their families? Alternatively, those same individuals could have been off put by the decadence of their Arab hosts and their maltreatment of South Asians living in their midst.

The Pakistan Army's varied efforts to Islamize the army had some successes. Cohen cites one senior officer who told him that "expressions like the 'ideology of Pakistan' and the 'glory of Islam,' normally outside a professional fighter's lexicon, were becoming stock phrases...The Service Chiefs sounded more like high priests than soldiers. ${ }^{, 89}$ Rizvi cites a retired officer who wrote that the cumulative effect of Zia's policies within the army was the "rise of religious orthodoxy among a cross-section of the armed forces. For this small group, ideology can be stretched to radicalism and takes precedence over professionalism. Their attitude needs to be countervailed, otherwise it will erode the very foundation of a cohesive, professionally competent, and technologically adept armed forces. ${ }^{, 90}$

Arguably, the changing ethos of the military would influence a recruit's interest in joining the military. Individuals who rejected Zia's vision or who were unwilling to pretend to do so may have been unlikely to join the army in the first place. Thus, any Islamization of the army could arise through top-down efforts from the army leadership but also from supply-side pressures that may have altered the distribution of attributes and attitudes of those seeking to join 
the officer corps in the first instance. Needless to say, there are no data that allow us to evaluate any of these possibilities.

Despite Zia's efforts to Islamize the army and the state, Cohen found that the changes in the officer corps, while important, were in fact quite modest at the time of his research. He also found that there was considerable divergence within the officer corps about Islam, which mirrored the divergence of views about the origins of the state and the role of Islam in it. ${ }^{91}$ Cohen did find other officers who were dissatisfied with the pace of Islamization of the military. He came across a number of officers who criticized the Staff College and rules of the army as having a "distinct aroma of subjugation suited to a colonial power" rather than "reflecting a true Islamic equalitarianism.",92

Some senior army leadership that came after Zia appreciated the impact of Zia's policies on the army and feared that some of members of the army had come to substitute "professionalism and discipline with Islam-oriented activism." $" 93$ General Asif Nawaz Janjua (who was the army chief between August 1991 and January 1993) and his successors tried to push back the politicized Islamic elements within the force and reinstate prior traditions of "keeping Islam and professionalism together but treating the former as a component of the latter." ${ }^{94}$ However, Zia's successors continued to acknowledge the role and importance of Islam within military ideology. ${ }^{95}$

Rizvi, anticipating contemporary concerns about the army, argued that the Pakistani military will face major challenges in the twenty-first century. First, it would have to ensure the professional and cohesive disposition as the new breed of officers who came up during the Zia years took command. Second, it would have to maintain the delicate balance between Islam and service discipline as Islamic and Islamist groups continued to develop inroads into the army. No 
doubt Pakistan's active utilization of Islamist militant groups as tools of foreign policy has fostered some deeply sympathetic elements within the army for whom abandoning "jihad" is very difficult. ${ }^{96}$

\section{ARMY RECRUITMENT: A DISTRICT-LEVEL ASSESSMENT ${ }^{97}$}

While questions about the Pakistan Army are extremely important, data do not exist that permit analysts to address them rigorously. Cooperation with the Pakistani government and the army in particular would be fundamental to collecting officer-level data needed to understand the role of Islam and Islamism within the Pakistani armed forces, the degree of support for militant groups, and the connections - if any — among support for militancy, personal piety, Islam and Islamism. Such cooperation is unlikely to be forthcoming.

Fortunately, recent district-level data on aggregate officer recruitments and retirement from 1970-2005 offer limited insights into the characteristics of the districts that produce

officers. ${ }^{98}$ Recruitment data pertain to annual numbers of candidates accepted into the Pakistan Military Academy at Kakul. Data are aggregated by the officer's district of origin. Areas of origin also include FATA, Kashmir and Gilgit-Baltistan, areas that are not typically included in Pakistan's federal surveys. The data set also includes district-level aggregates of the numbers of officers who retired from those districts.

The optimal empirical approach to understanding changes in the officer corps requires analysis of the social and economic characteristics of individual officers, which do not exist publicly. Per force, this study uses a "second best" approach that studies the characteristics of officers' homedistricts and how these have changed over time. This approach provides some insights into the larger social and economic environment of those districts that produce officers 
including proxies for social conservatism. Despite the sub-optimal nature of the data, they do permit us to evaluate claims that the Pakistani army has increasingly recruited from socially conservative areas over the years even while they cast no light upon the characteristics of individual officer candidates. The data, methods and results are briefly recounted below.

\section{Data: A Brief Overview ${ }^{99}$}

This study employs two kinds of data. First, it uses annual army data which provide district-level aggregated recruits and retirements between 1970 and 2005. (Figure 1 shows the annual intake of officers into the PMA, aggregated annually across all districts.)

Figure 1. Annual Intake of Officersfor All Provinces(1970-2005)

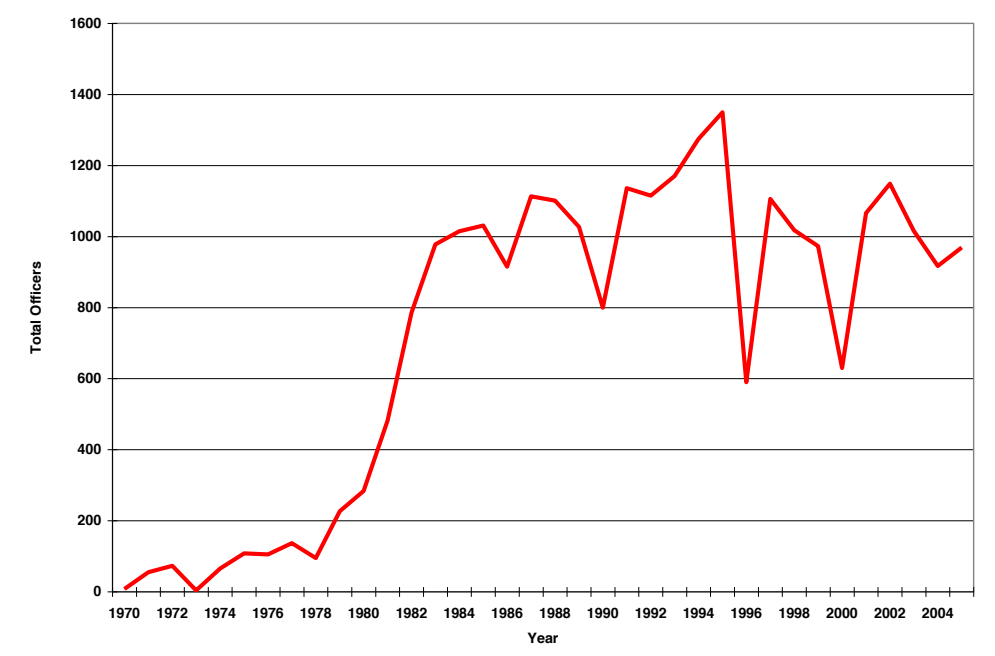

Source: In-house manipulations of army officer recruitment data.

Second, it utilizes district-level estimates of economic, demographic, and social characteristics derived from the 1991, 1995, 1998, and 2001 waves of household surveys which are conducted by Pakistan's Federal Bureau of Statistics (FBS). These survey data are comprised of household surveys as well district-level assessments of facilities and government services for 
the four provinces of the Punjab, Sindh, Baluchistan and KPK. The data analyst created weights to collapse data to annual, district-level observations to match the army recruiting and retirement data.

The analytical dataset was constructed using only those district/years for which three conditions hold. First, recruitment data are used only in years for which household survey data exist in all waves of the FBS data. Second, recruitment data are used only for those years for which one-year "lag" variables (e.g. years in which data for the following year were also available) could be created. Arguably socio-economic and other household variables would not affect recruitment outcomes in the same year. Third, models use only those district/years for which the full set of individual and community characteristics were collected by the FBS across all years in each district. In resultant dataset included recruitment data from 1992, 1996, 1999 and 2002 for those districts that fell within the four provinces and district-matched FBS data from 1991, 1995, 1998 and 2001. These cumulative restrictions yielded with a data set of 343 observations (4 years for each of 98 districts in the army data).

\section{Methods and Analysis}

A panel regression is used to model the determinants of variation observed in officer recruitments across the districts and across time. The model is given by:

$(\text { Recruits })_{\mathrm{i}, \mathrm{t}}=\alpha(\text { demographic })_{\mathrm{i}, \mathrm{t}-1}+\beta(\text { economic })_{\mathrm{i}, \mathrm{t}-1}+\gamma(\text { social })_{\mathrm{i}, \mathrm{t}-1}$

$+\delta(\text { military })_{\mathrm{i}, \mathrm{t}-\mathrm{1}}+\mu_{\mathrm{i}}+\tau_{\mathrm{t}}+\varepsilon_{\mathrm{I}, \mathrm{t}}$

This model includes several vectors of demographic, economic, and what we call "social liberalism" variables as well as a variable which reflects the accumulating "military capital" of the district as reflected by the retirees in a district. The model also includes year $(\tau)$ and district $(\mu)$ fixed effects. 
Demographic variables for the district include: the percentage of the district that is urban; the share of the population that is male and between 20 and 29 years of age (the military's "target market), as well as the percentage of persons in the district who can do simple math problems (in lieu of literacy which is poorly defined). Because one of our key social-liberalism indicators is the difference in male and female attainment, these variables could not be used as demographic indicators for the district.

District economic indicators include the district Gini coefficient, total male and female labor force participation, the average number of private high schools per district as a measure of demand for elite education, and average numbers of public high schools and public high schools in a district as a measure of state investment.

Social liberalism proxies, which are at the core of this study, include the average age of female at first marriage; the numbers of sons in a household in private schools divided by all sons in the household; the average number of family planning clinics in a district; and the difference in educational differences of males and females. Table 1 provides the descriptive statistics for the dependent and independent variables for those districts and years which were used in the model and Table 2 provides the results of the panel-regression analysis for recruitment outcomes. 
Table 1. Summary Statistics for the Dependent Variables(1992, 1996, 1999, and 2002) and Independent Variables(1991, 1995, 1998, 2001)

\begin{tabular}{|c|c|c|c|c|c|}
\hline Variable & Obs & Mean & $\begin{array}{l}\text { Std. } \\
\text { Dev. }\end{array}$ & Min & Max \\
\hline Recruits $^{*}$ & 343 & 9.53 & 20.22 & 0.00 & 194.00 \\
\hline \multicolumn{6}{|l|}{ District demographics ${ }^{A}$} \\
\hline Percent urban & 343 & 0.31 & 0.4 & 0 & 1 \\
\hline $\begin{array}{l}\text { Share of population that is male b/w } 20 \text { and } 29 \\
\text { years of age }\end{array}$ & 343 & 0.08 & 0.01 & 0.04 & 0.12 \\
\hline Ability to do simple addition & 343 & 0.67 & 0.21 & 0.20 & 1.0 \\
\hline \multicolumn{6}{|l|}{ District Economics ${ }^{B}$} \\
\hline District Gini (income) & 343 & $.5^{0}$ & $.14^{0}$ & .18 & $82^{0 .}$ \\
\hline Labor Force Participation & 343 & $.22^{0}$ & $.11^{0}$ & .10 & 50 \\
\hline $\begin{array}{l}\text { Average number of private high schools per } \\
\text { district. }\end{array}$ & 343 & $.06^{1}$ & $.93^{3}$ & & 66 \\
\hline $\begin{array}{l}\text { Average number of public high schools per } \\
\text { district. }\end{array}$ & 343 & $.4^{3}$ & $.29^{7}$ & & 94 \\
\hline Average number of public hospitals per district & 343 & 0.27 & 0.83 & 0 & 9 \\
\hline \multicolumn{6}{|l|}{ District social liberalism ${ }^{\mathrm{c}}$} \\
\hline Average age of female at first marriage & 343 & 19.18 & 2.42 & 15.29 & 26.23 \\
\hline Private school son density *** & 343 & 0.05 & 0.06 & 0 & 0.25 \\
\hline $\begin{array}{l}\text { Average number of family planning clinics in a } \\
\text { district }\end{array}$ & 343 & 1.77 & 5.62 & 0 & 94 \\
\hline $\begin{array}{l}\text { Differ ences in male ed. attainment compared to } \\
\text { female ed. attainment. }\end{array}$ & 343 & 1.21 & 1.44 & -5.25 & 6.28 \\
\hline \multicolumn{6}{|l|}{ District military ${ }^{A}$} \\
\hline Retirees & 343 & $.58^{0}$ & $.97^{1}$ & d & 27 \\
\hline
\end{tabular}

SOURCE: ${ }^{\mathrm{A}}$ In-house tabulations based on Army recruitment data. ${ }^{\mathrm{B}}$ In-house tabulations of FBS data.

${ }^{\mathrm{C}}$ Average proportion within district/year of male children in a household sent to private school. 
Table 2. Panel Regression Results for District Recruits

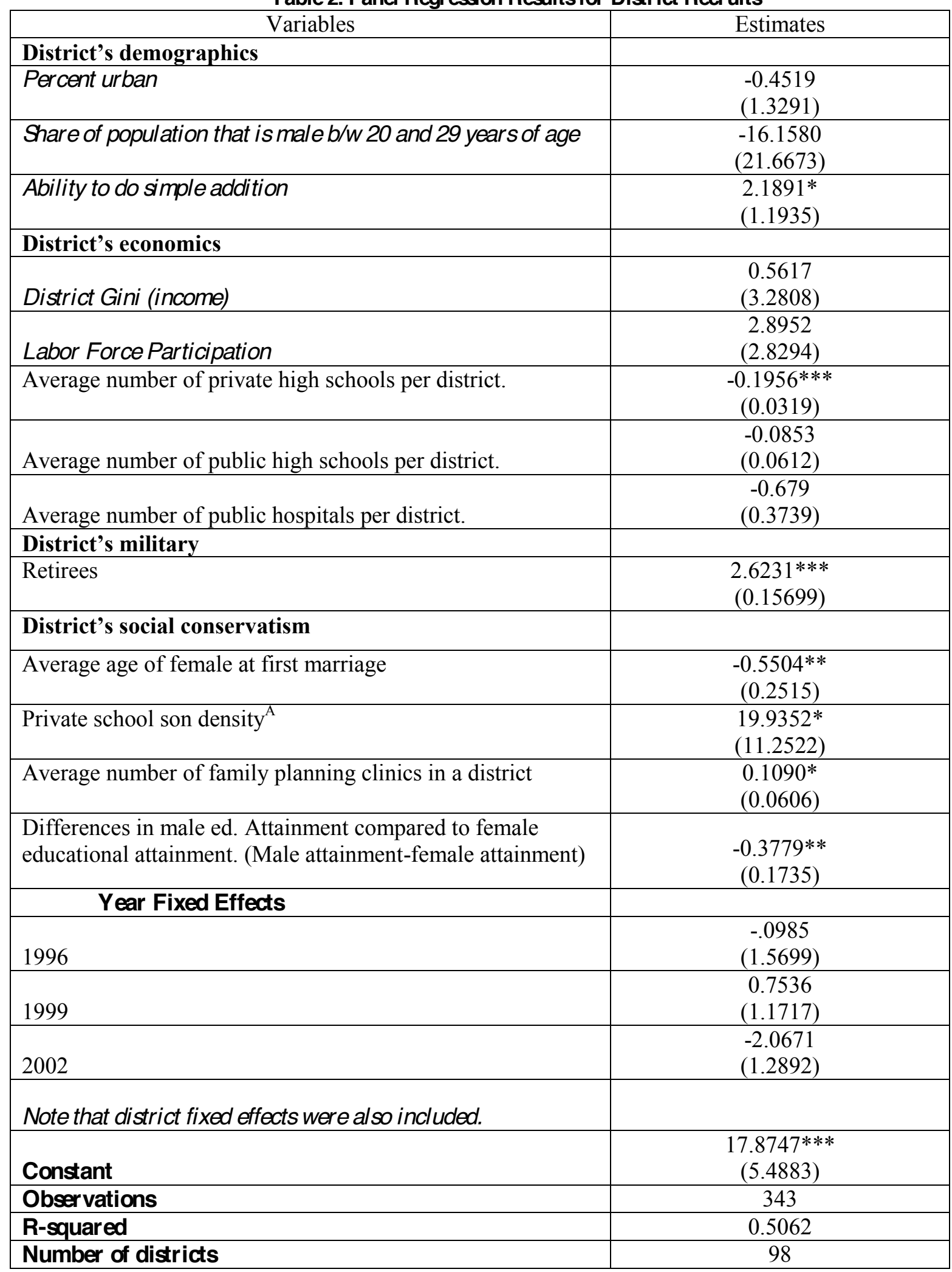

NOTE: The coefficients represent maximum likelihood estimates of a panel-regression model. Dependent variable is a proxy for the Army officer's recruiting intensity in at district i in time $t$, and the explanatory variables 
are measured for district i in time t-1. All regressions include year and district fixed effects. Standard errors are in parenthesis. $* * *$ indicates statistically significant at $1 \%$ level; ** indicates statistically significant at $5 \%$ level; * indicates statistically significant at $10 \%$ level. ${ }^{A}$ Average proportion within district/year of male children in a household sent to private school.

Four key findings emerge from the panel regression estimates. First, among the demographic variables only the ability to do simple arithmetic is significant and positive. This suggests that foundational human capital matters to the army, as expected. While overall, more officers are coming from urban areas, when other district-level demographic characteristics (e.g. wealth, education, literacy, etc.) are included, the urban effect disappears.

Second, private high schools in a district are significantly and negatively correlated with recruitment. Large numbers of private high schools reflect a market demand for higher quality education. Given that overall attainment in Pakistan is low (about 8 years), families investing in private schools likely expect immediate payoffs in the labor market which is not likely in the early years of a military career.

Third, the presence of retired officers is a strong and significant predictor of recruitment outcomes. This suggests that retirees are important influencers who positively affect the disposition towards joining the Pakistani army corps. (Similar results obtain for U.S. army recruitment. ${ }^{100}$ ) It likely proxies lower transaction costs for pursuing a military career as well.

Fourth, among the social liberalism variables, density of male private school enrollment is positively and significantly associated with recruitment. Private-school utilization correlates with socially liberal views in Pakistan. ${ }^{101}$ Similarly, in districts where male education exceeds female educational attainments, recruitment is less likely. The presence of family planning clinics is also positively and significantly correlated with recruitment. These three findings suggest that more socially liberal districts aremore likely to produce officers rather than socially conservative 
ones. However, as the age at first marriage for females increases, recruitment declines. Deferred marriage reflects higher education attainment for women, which could not be used in this model. This finding does not necessarily proxy increasing conservativism.

Previous published descriptive (rather than regression) analysis of these data has demonstrated that, over time, the Pakistan Army has expanded the geographical distribution of officer recruitment. While recruits from Punjab and KPK are somewhat overrepresented in annual cohorts, Balochistan appears to be producing recruits roughly in proportion to that province's population distribution. In contrast, Sindh is massively underrepresented in new officer intake per its share of Pakistan's population. ${ }^{102}$

These geographical changes in recruitment outcomes may have important implications for the role of Islam, piety and support for extremism. For example, Pashtuns are often characterized (with little empirical evidence) as being "more pious" than others in Pakistan. This claim is impossible to verify with current data and may be a reflection of pervasive stereotypes about Pashtuns held among Pakistanis. However, if this is true, the high proportion of Pashtuns relative to their population in Pakistan-could auger changes in the distribution of attitudes in the army. Perhaps more important however is the ongoing insurgency in Pakistan, which is spearheaded by the "Pakistani Taliban" and is anchored in the Pashtun belts. ${ }^{103}$ It is too early to discern how this insurgency, which is going on its seventh year, will affect officer attitudes towards extremism.

\section{CONCLUSIONS AND I M PLICATIONS}

The Pakistan army has used Islam for a variety of institutional and national goals. Elements of the army have indeed radicalized as evidenced by the rare — but increasing and devastating — terrorist attacks in Pakistan that have involved military personnel. However, the 
ecological study of the districts that produce officers suggests that there is no systematic evidence that conservative areas produce more officers, per our metrics of social conservatism. By extension, this suggests that the army is not actively targeting conservative districts for recruitments. This analysis finds the opposite to hold that social liberal districts produce more officers. The biggest predictors of recruitment in any given year were economic shocks in the previous year and previous recruitments and retirements of the district.

Given the importance of the query, clearly the available data is inadequate to systematically assess the degree of Islamization of the officer corps, and more importantly, the sympathies that may exist within the corps for violent extremism. This does suggest an urgent research agenda, despite potentially formidable opposition by the Pakistan Army to the same. Sophisticated, large sample, multi-wave surveys of military and non-military households may be one such approach that could cast much-needed light on the role of Islam, attitudes towards Islamism, pietistic trends, and beliefs about Islamist militancy in the single-most important institution that sets the course for Pakistan external as well as domestic policies.

${ }^{1}$ Pakistan has an army, an air force and navy among several paramilitary organizations. However, the army is the most important because of its long-standing role in governing the country directly or indirectly.

${ }^{2}$ Jonathan Paris, Prospects for Pakistan, (London: The Legatum Institute, January 2010), http://www.li.com/attachments/ProspectsForPakistan.pdf (accessed September 7, 2011); 'General Kayani seeks to repair dented army pride,", Pakistan Express Tribune, June 20, 2011, http://tribune.com.pk/story/192512/generalkayani-seeks-to-repair-dented-army-pride/( accessed September 7, 2011).

${ }^{3}$ Husain Haqqani, Pakistan: Between Mosque and Military (Washington, D.C.: Carnegie Endowment for International Peace, 2005), 103-5, 167-68; Barnett R. Rubin, The Fragmentation of Afghanistan (New Haven: Yale University Press, 2002), 83-84; and Rizwan Hussain, Pakistan and the Emergence of Islamic Militancy in Afghanistan (Burlington: Ashgate, 2005), 79-81. For an example of such fears, see Paris, Prospects for Pakistan. For a countervailing view, see C. Christine Fair et al., Pakistan: Can the United States Secure and Insecurity State? 
(Santa Monica: RAND, 2010) and Julian Schofield, and Michael Zekulin, Appraising the Threat of Islamist TakeOver in Pakistan, Concordia University Research Note 34, March 2007, http://www.ieim.uqam.ca/IMG/pdf/NOTE34.pdf (accessed September 7, 2011).

${ }^{4}$ This has been the subject of numerous U.S. government-funded gaming and scenario exercises. See the exposition of Clifford May making this argument during his interview with Kathleen Parker and Eliot Spitzer (aka "Parker Spitzer") on December 28, 2010 at 8 p.m. EST, http://parkerspitzer.blogs.cnn.com/2010/12/28/

${ }^{5}$ Without evidence, Paris writes that "The danger for the army, and for Pakistan generally, is not Talibanisation but Islamisation from Punjab-based militants and their allies." Paris also fails to describe what he means by "Islamisation" and why this is necessarily dangerous. This analysis suggests Islamists are more prone to hand the country to terrorists. Paris, Prospects for Pakistan, 7.

${ }^{6}$ See Stratfor, "Pakistan and its Army," November 6, 2007, http://www.billoreilly.com/b/Pakistan-and-itsArmy/197757057850630219.html (accessed September 7, 2011).

7 David Leigh, "WikiLeaks cables expose Pakistan nuclear fears: US and UK diplomats warn of terrorists getting hold of fissile material and of Pakistan-India nuclear exchange," The Guardian, November 30, 2010, http://www.guardian.co.uk/world/2010/nov/30/wikileaks-cables-pakistan-nuclear-fears (accessed September 7, 2011).

${ }^{8}$ Syed Saleem Shahzad, "Al-Qaeda had warned of Pakistan strike," The Asia Times, May 27, 2011, http://www.atimes.com/atimes/South Asia/ME27Df06.html (accessed September 7, 2011).

9 "Two Soldiers Convicted in Musharraf Assassination Attempts," VOA News, December 24, 2011, http://www.voanews.com/english/news/a-13-2004-12-24-voa35-67335172.html (accessed September 7, 2011).

${ }^{10}$ Muqaddam Khan and Azaz Syed, "Ex-soldier, brothers held on Tarbela attack suspicion," The Daily Times, September 15, 2007, http://www.dailytimes.com.pk/default.asp?page=2007/09/15/story 15-9-2007 pg1 7 (accessed September 7, 2011).

${ }^{11}$ Jane Parlez, "Pakistan Retakes Army Headquarters; Hostages Freed," The New York Time,, October 10, 2009, http://www.nytimes.com/2009/10/11/world/asia/11pstan.html (accessed September 7, 2011).

${ }^{12}$ Many of these attacks involved civilian personnel, junior officers, enlisted personnel from the army, navy, air force, police, and paramilitary organizations. See Raza Rumi, “The Spectre of Islamist Infiltration,” The Friday Times, May 27, 2011, http://www.thefridaytimes.com/27052011/page3.shtml (accessed September 7, 2011).

13 Karin Brulliard "Pakistan's top military officials are worried about militant collaborators in their ranks," The Washington Post, May 17, 2011, http://www.washingtonpost.com/world/pakistani-military-worried-aboutcollaborators-in-its-ranks-officials-say/2011/05/27/AGgN1oCH story.html (accessed September 7, 2011).

${ }^{14}$ For a critique of this presumed "Islamist Threat," see Frédéric Grare, Pakistan: The Myth of an Islamist Peril, Policy Brief 45, (Washington D.C.: CEIP, 2006).

${ }^{15}$ David Leigh, "WikiLeaks cables expose Pakistan nuclear fears: US and UK diplomats warn of terrorists getting hold of fissile material and of Pakistan-India nuclear exchange," The Guardian, November 30, 2010, 
http://www.guardian.co.uk/world/2010/nov/30/wikileaks-cables-pakistan-nuclear-fears (accessed September 7, 2011). For an extremely thoughtful and critical take on the views that exist in Pakistan, see Shahid M. Amin, "A state of denial," The Dawn, October 21, 2009, http://news.dawn.com/wps/wcm/connect/dawn-contentlibrary/dawn/news/pakistan/14-a-state-of-denial-zj-06 (accessed September 7, 2011).

${ }^{16}$ C. Christine Fair, Neil Malhotra, Jacob N. Shapiro, "Islam, Militancy, and Politics in Pakistan: Insights from a National Sample," Terrorism and Political Violence 22, 4 (2010): 495-521.

${ }^{17}$ See Asad Farooq, "Western media propagating anti-Muslim sentiments," The Daily Times, December 15,

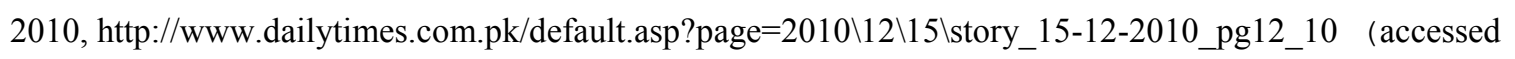
September 7, 2011).

${ }^{18}$ Stephen P. Cohen, The Pakistan Army (Berkeley: University of California Press, 1984); Brian Cloughley, A History of the Pakistan Army: Wars and Insurrections (Karachi: OUP, 1999).

${ }^{19}$ Ayesha Jalal, The State of Martial Rule: The Origins of Pakistan's Political Economy of Defence (Cambridge: Cambridge University Press, 1990).

${ }^{20}$ Hassan Askari Rizvi, Military, State and Society in Pakistan (London: Palgrave, 2000); Hassan Askari Rizvi, The Military and Politics in Pakistan: 1947-1997 (Lahore, Pakistan: Sang-e-Meel Publications, 2000).

${ }^{21}$ Shuja Nawaz, Crossed Swords: Pakistan, Its Army and the Wars Within (New York: OUP, 2008); Ayesha Siddiqa, Military Inc.: Inside Pakistan's Military Economy (London: Pluto Press, 2007).

${ }^{22}$ Haqqani, Pakistan.

${ }^{23}$ Hussain, Pakistan.

${ }^{24}$ C. Christine Fair, The Counterterror Coalitions: Cooperation with Pakistan and India (Santa Monica: RAND, 2004).

${ }^{25}$ Ashley J. Tellis, Pakistan and the War on Terror Conflicted Goals, Compromised Performance (Washington D.C.: CEIP, 2008), http://www.carnegieendowment.org/files/tellis pakistan final.pdf. 26 Yochi J. Dreazen, "Fear That U.S. Can Grab Nuclear Arsenal Heightens Pakistani Anger," National Journal, May 9, 2011, http://www.nationaljournal.com/nationalsecurity/fear-that-u-s-can-grab-nuclear-arsenalheightens-pakistani-anger-20110509?page $=1 \&$ sms ss=twitter\&at $\mathrm{xt}=4 \mathrm{dc} 7 \mathrm{c} 790 \mathrm{a} 8 \mathrm{ec} 72 \mathrm{c} 6,0$ (accessed September 7, 2011).

${ }^{27}$ This judgment is based upon the author's years of research in Pakistan, discussion with American military attaches in Pakistan and conversations with numerous Foreign Area Officers specializing in Pakistan since 1999.

${ }^{28}$ Robert G. Wirsing, "Political Islam, Pakistan, and the Geo-Politics of Religious Identity," in Yoichiro Sato, Growth and Governance in Asia (Honolulu: APCSS, 2004), 173.

${ }^{29}$ Owen Bennet Jones, Pakistan: eye of the storm (New Haven: Yale University Press, 2003), 257.

${ }^{30}$ For a more detailed account of army officer recruitment, see C. Christine Fair and Shuja Nawaz, "The Changing Pakistan Army Officer Corps," Journal of Strategic Studies 34, 1 (February 2011): 63-94.

${ }^{31}$ Fair and Nawaz, "The Changing Pakistan Army Officer Corps." 
${ }^{32}$ Official website of the Pakistan Army, "Join Pakistan Army: Men at their Best," n.d., http://www.joinpakarmy.gov.pk/ (accessed September 7, 2011).

${ }^{33}$ Official website of the Pakistan Army.

${ }^{34}$ Fair and Nawaz, "The Changing Pakistan Army Officer Corps."

${ }^{35}$ Heather Street, Martial Races: The Military, Race and Masculinity in British Imperial Culture, 1857-1914 (Vancouver: University of British Columbia press, 2004).

${ }^{36}$ Nasr articulates the process of Islamization as ensconcing "Islamic norms, symbols and rhetoric in the public sphere, and in the process, it has had a notable impact on politics, policy making, law and social relations." See Seyyed Vali Reza Nasr, Islamic Leviathan: Islam and the Making of State Power (Oxford: OUP, 2001), 3.

${ }^{37}$ See Farzana Shaikh. Making Sense of Pakistan (New York: Columbia/Hurst, 2009).

${ }^{38}$ Mohammad A. Qadeer, Pakistan: Social and Cultural Transformations in a Muslim Nation (London: Routledge, 2005).

${ }^{39}$ Nasr, Islamic Leviathan.

${ }^{40}$ General Zia was appointed the Chief of Army Staff by then Prime Minister Bhutto. He overthrew Bhutto in a coup and declared himself Chief Martial Law Administrator in 1977. He later installed himself as president in 1978. He remained president and chief of army staff until his death in August 1988.

${ }^{41}$ Hassan Askari Rizvi. Military, State and Society in Pakistan (London: Palgrave, 2000), 170.

${ }^{42}$ Rizvi, Military, State and Society in Pakistan, 171. See also Nasr, Islamic Leviathan.

${ }^{43}$ Rizvi, Military, State and Society in Pakistan, 171-72.

${ }^{44}$ Rizvi, Military, State and Society in Pakistan, 171-72; Nasr, Islamic Leviathan.

${ }^{45}$ Cohen, The Pakistan Army, 170-173.

${ }^{46}$ C. Christine Fair, Madrassah Challenge: Militancy and Religious Education in Pakistan (Washington D.C: USIP, 2008).

${ }^{47}$ Qadeer, Pakistan, 176. Also see Richard Kurin, "Islamization: A View from the Countryside," in Anita Weiss Ed., Islamic Reassertion in Pakistan (Syracuse: Syracuse University Press, 1986), 115-128.

${ }^{48}$ Qadeer, Pakistan, 176-177; see also Kurin, "Islamization."

${ }^{49}$ Vali Nasr, "Military Rule, Islamism and Democracy in Pakistan," Middle East Journal 58, 2 (Spring, 2004): 195-209.

${ }^{50}$ See Anatol Lieven, Pakistan: a Hard Country (London: Penguine, 2011), 27, 204-258.

${ }^{51}$ The Pew Foundation Global Attitudes Survey has regularly surveyed Pakistan since 2001 with an overwhelmingly urban sample using a somewhat similar core set of questions as well as new questions. The questions are poorly worded and they have yielded extremely high non-response rates. Other surveys are done regularly but respondent-level data are not available to the public.

${ }^{52}$ The World Values Survey did survey Pakistan in 1997 and 2001. Unfortunately, between these two years, the organization changed their questionnaire precluding anyone from making any comparisons across the two years 
for variables of interests in this study. See World Values Survey's website,

http://www.wvsevsdb.com/wvs/WVSAnalizeStudy.jsp (accessed September 7, 2011).

${ }^{53}$ Fair, Malhotra, Shapiro, "Islam, Militancy, and Politics in Pakistan;" Jacob N. Shapiro and C. Christine

Fair, "Why Support Islamist Militancy? Evidence from Pakistan," International Security 34, 3 (Winter 2009/2010):

$79-118$.

${ }^{54}$ Cohen, Pakistan Army, 37.

${ }^{55}$ Martin Axmann, Back to the Future: The Khanate of Kalat and the Genesis of Baluch Nationalism 1915-

1955(New York: OUP, 2008).

${ }^{56}$ Ian Talbott, Pakistan: A Modern History (New York: St. Martin’s Press, 1998), 21-52.

${ }^{57}$ Rizvi, Military, State and Society in Pakistan, 245.

${ }^{58}$ S.V. R. Nasr, "Islam, The State, and the Rise of Sectarian Militancy," in Christophe Jaffrelot Ed.,

Pakistan: Nationalism Without A Nation (London: Zed Books, 2002), 85-114; Mariam Abou Zahab, "The Regional Dimensions of Sectarian Conflict in Pakistan, “ in Jaffrelot Ed., Pakistan, 115-130.

${ }^{59}$ Haqqani, Pakistan, 51-86.

${ }^{60}$ Hassan Askari Rizvi, The Military and Politics in Pakistan: 1947-1997 (Lahore: Sang-e-Meel, 2000), 256.

${ }^{61}$ Rizvi, The Military and Politics, 256.

${ }^{62}$ Pervaiz Iqbal Cheema, The Armed Forces of Pakistan (Karachi: Oxford University Press 2002), 82.

${ }^{63}$ Cheema, Armed Forces, 82.

${ }^{64}$ Dr. S. M. Rahman, "Motivation: The Ultimate Weapon," The Dawn, September 6, 1984 cited by Cheema,

Armed Forces, 82.

${ }^{65}$ Cited by Cohen, Pakistan Army, 87.

${ }^{66}$ Brig. Javed Hassan, India: A Study in Profile (Rawalpindi: Services Book Club, 1990).

${ }^{67}$ See National Defense University, "Important Books to Read," n.d.

www.ndu.edu.pk/SOPs/war wing/books list.doc (accessed September 7, 2011).

${ }^{68}$ Hassan, India, 49.

${ }^{69}$ Hassan, India, 53.

${ }^{70}$ Hassan, India, 54.

${ }^{71}$ Hassan, India, 181-214.

${ }^{72}$ Haqqani, Pakistan, 171-7.

${ }^{73}$ Alexander Evans, "The Kashmir Insurgency: As Bad as It Gets," Small Wars and Insurgencies 11, 1

(Spring 2000): 69-81. For Pakistani groups' efforts to undermine Kashmiri groups, see Arif Jamal, Shadow War:

The Untold Story of Jihad in Kashmir (New York: Melville House, 2009), 131-179.

${ }^{74}$ Veena Kukreja, Contemporary Pakistan (New Delhi: Sage, 2003), 68.

${ }^{75}$ Nasr, Islamic Leviathan.

${ }^{76}$ Rizvi, Military, State and Society in Pakistan, 246. 
${ }^{77}$ Rizvi, Military, State and Society in Pakistan, 245.

${ }^{78}$ Cohen, Pakistan Army, 95.

${ }^{79}$ Cohen, Pakistan Army, 38-39.

${ }^{80}$ Rizvi, Military, State and Society in Pakistan, 245.

${ }^{81}$ Rizvi, Military, State and Society in Pakistan, 245-46.

${ }^{82}$ Rizvi, Military, State and Society in Pakistan, 246.

${ }^{83}$ Rizvi, Military, State and Society in Pakistan, 245.

${ }^{84}$ Rizvi, Military, State and Society in Pakistan, 245.

${ }^{85}$ The date of deployment is note publically available. However, the brigade was withdrawn in 1988 when the last commander, General Jehangir Karamat, departed. See Atlantic Council, Łakistan Army Challenges: General Jehangir Karamat," July 1, 2009, http://www.acus.org/event/challenges-facing-pakistan-army.

${ }^{86}$ Jamal Rashid, "Pakistan and the Central Command," MERIP Middle East Middle East Report, 141 (July/August 1996), 28-34. See note 8 '“US Security Interests in South Asia,' staff report prepared by the Committee on Foreign Relations, US Senate, April 19, 1984. Also see "Pakistan Armed Forces," Scramble Magazine, Online, n.d. (date given is wrong September 1, 109), http://www.scramble.nl/pk.htm (accessed September 7, 2011).

${ }^{87}$ Simon Henderson, "Pakistan, Proliferation, and the Middle East," Washington Institute for Near East

Policy Policy Watch \#415, October 14, 1999, http://www.washingtoninstitute.org/templateC05.php?CID=1293 (accessed September 7, 2011).

${ }^{88}$ Miranda Husain, "Bahrain or Bust?" Newsweek Pakistan, April 11, 2011, http://www.newsweekpakistan.com/the-take/287 (accessed September 7, 2011).

${ }^{89}$ Cited by Cohen, Pakistan Army, 87.

${ }^{90}$ Cited in Rizvi, Military, State and Society in Pakistan, 247.

${ }^{91}$ Cohen, Pakistan Army, 37.

${ }^{92}$ Cohen, Pakistan Army, 96.

${ }^{93}$ Rizvi, Military, State and Society in Pakistan, 247.

${ }^{94}$ Rizvi, Military, State and Society in Pakistan, 247.

${ }^{95}$ Pakistani military officers' oath is specified in the Pakistani Constitution, Third Schedule, Article 244. "(In the name of Allah, the most Beneficent, the most Merciful.) $\mathrm{I}$, , do solemnly swear that I will bear true faith and allegiance to Pakistan and uphold the Constitution of the Islamic Republic of Pakistan which embodies the will of the people, that I will not engage myself in any political activities whatsoever and that I will honestly and faithfully serve Pakistan in the Pakistan Army (or Navy or Air Force) as required by and under the law. May Allah Almighty help and guide me (A'meen).

${ }^{96}$ Rizvi, Military, State and Society in Pakistan, 248. 
${ }^{97}$ The author thanks Graem Blaire, Jacob N. Shapiro and Claude Berrebi for conducting the data handling and running of the models.

${ }^{98}$ Fair and Nawaz, "The Changing Pakistan Army Officer Corps.”

${ }^{99}$ For a more detailed exposition of methods, see Fair and Nawaz, "The Changing Pakistan Army Officer Corps."

${ }^{100}$ Bruce R. Orvis, Martin T. Gahart, and Karl Schutz, Enlistment among Applicants for Military Service: Determinants and Incentives (Santa Monica: RAND, 1990); Bruce R. Orvis, Narayan Sastry, and Laurie L. McDonald, Military Recruiting Outlook: Recent Trends in Enlistment Propensity and Conversion of Potential Enlisted Supply (Santa Monica: RAND, 1996); and Bruce R. Orvis and Beth J. Asch, Military Recruiting: Trends, Outlook, and Implications(Santa Monica: RAND, 2001).

${ }^{101}$ Tahir Andrabi, Jishnu Das, Asim Khwaja, and Tristan Zajonc, "Religious School Enrollment in Pakistan: A Look at the Data,” John F. Kennedy School of Government Working Paper, no.

RWP05-024, March 2005. Available at web.hks.harvard.edu/publications/getFile.aspx?Id=169 (accessed September 7, 2011).

102 Because these refer to places of origin rather than ethnicity, one cannot discern if someone from Baluchistan is ethnically Baloch or Punjabi, for example. Fair and Nawaz, "The Changing Pakistan Army Officer Corps."

${ }^{103}$ Seth G. Jones and C. Christine Fair, Counterinsurgency in Pakistan (Santa Monica: RAND, 2010). 


\section{Mortara Working Paper Series}

For the full list, visit http://mortara.georgetown.edu/papers/

Address: Mortara Center for International Studies, Georgetown University, 3600 N Street, NW, Washington, DC 20057.

Lim, Daniel Yew Mao and James Raymond Vreeland. 2011. Regional Organizations and International Politics: Trading Asian Development Bank Loans for United Nations Security Council Votes. Georgetown University, Mortara Center Working Paper 2011-1.

Oldenski, Lindsey. 2010. Export Versus FDI: A Task-Based Approach. Georgetown University, Mortara Center Working Paper 2011-2.

Oldenski, Lindsey. 2011. The Task Composition of Offshoring by U.S. Multinationals. Georgetown University, Mortara Center Working Paper 2011-3.

Owen, Erica and Dennis Quinn. 2011. Does Economic Globalization Influence the U.S. Policy Mood?: A Study of U.S. Public Sentiment, 1956-2008. Georgetown University, Mortara Center Working Paper 2011-4.

Gete, Pedro. Housing Markets and Current Account Dynamics. 2010. Georgetown University, Mortara Center Working Paper 2011-5.

Fair, Christine C, Karl Kaltenhaler and William J. Miller. 2011. Iranians and the Bomb: Tales from the Demand Side. Georgetown University, Mortara Center Working Paper 2011-6.

Blair, Graeme et al. 2011. Poverty and Support for Militant Politics: Evidence from Pakistan. Georgetown University, Mortara Center Working Paper 2011-7.

Fair, Christine C., Neil Malhotra and Jacob N. Shapiro. 2011. Democratic Values and Support for Militancy: Evidence from a National Survey of Pakistan. Georgetown University, Mortara Center Working Paper 2011-8.

Dreher, Alex and James Raymond Vreeland. Buying Votes and International Organizations. Georgetown University, Mortara Center Working Paper 2011-9.

Kroenig, Matthew and Michael Weintraub. 2011. The Nuclear Balance and International Conflict. Georgetown University, Mortara Center Working Paper 2011-10.

Schneider, Christina and Jennifer Tobin. Interest Coalitions and Multilateral Aid Allocation in the European Union. Georgetown University, Mortara Center Working Paper 2011-11.

McNamara, Kathleen R. Historicizing the Unique: Why EMU Has No Fiscal Authority and Why it Matters. Georgetown University, Mortara Center Working Paper 2011-12. 